\title{
UZH: Alma Mater and Birthplace of Polyphor Ltd
}

\author{
Daniel Obrecht* ${ }^{\star}$ Jean-Pierre Obrecht, and Michael Altorfer
}

\begin{abstract}
Daniel and Jean-Pierre Obrecht and Michael Altorfer present a brief account of the role that the Institute of Organic Chemistry, University of Zurich, has played in their scientific and professional development leading ultimately to a successful business and the development of a new drug discovery technology.
\end{abstract}

Keywords: Cyclic depsipeptides · Combinatorial chemistry · Medicinal chemistry $\cdot$ Peptide mimetics . Protein epitope mimetics · University of Zurich

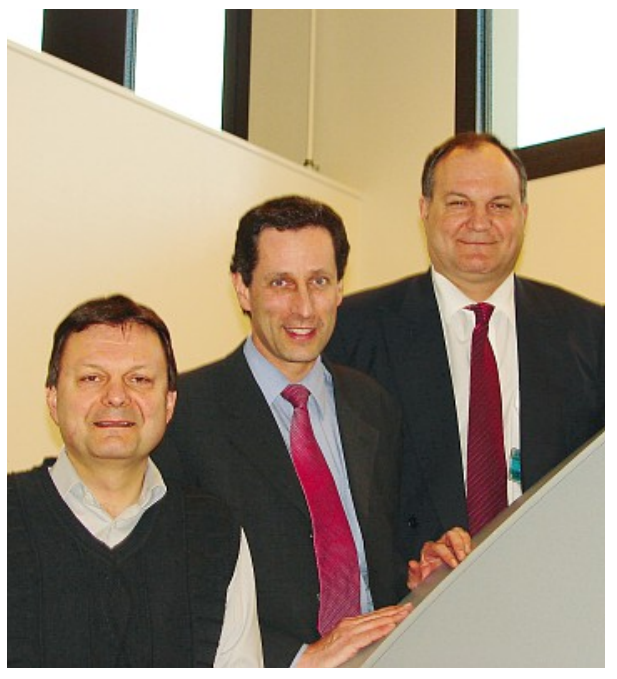

Daniel Obrecht, Michael Altorfer and Jean-Pierre Obrecht
In honour of 175 years of chemistry at the University of Zurich we would like to highlight the important role that the OCI has played in several periods of our scientific and professional careers and which has ultimately led to a successful business and the development of a new drug discovery technology.

\section{5-1983}

Daniel Obrecht's first contact with the OCI was in summer 1975 when Prof. Heinz Heimgartner, in his role as 'Studienberater', promoted the advantages and privileges of studying chemistry at the University of Zurich in a very convincing manner. The institute at that time was still located on the Rämistrasse, close to the city center. The aura of the late Nobel laureate Paul Karrer still seemed to fill the hallway of the venerable building. Prof. Hans Schmid was the charismatic leader of the institute at that time - respected and feared by the students. His sudden death in 1976 marked a clear turning point in the history of the institute. Daniel still remembers very well some of the inspiring chemistry courses held by Profs. A. Dreiding, M. Viscontini, M. Hesse, C. Eugster and H. Heimgartner as well as the excellent quality of the practical lab courses given by Drs. M. Karpf, M. Siegfried, P. Rüedi, R. Schmid, and others. The late seventies were marked by the move of the institute to the brand new Irchel campus. In 1980, after the move, Daniel finished his diploma work in the new labs and started his $\mathrm{PhD}$ thesis entitled '3-Amino$2 \mathrm{H}$-azirines as Amino Acid Equivalents in Organic Synthesis' ${ }^{[1]}$ under the guidance of Prof. H. Heimgartner, which was completed in 1983. "It was my first contact with the fascinating field of peptide mimetics and macrocyclic natural products (Fig. 1)".

\section{5-1996}

After post-doctoral studies at Caltech in Prof. Dr. R. E. Ireland's group working towards the total synthesis of the macrolactone natural product avermectin A2, Daniel joined the Central Research Laboratories of F. Hoffmann-La Roche in Basel under the supervision of Prof. Dr. H.-J. Hansen. In 1988 Prof. Hansen accepted a professorship at the OCI at the University of $\mathrm{Zu}$ -

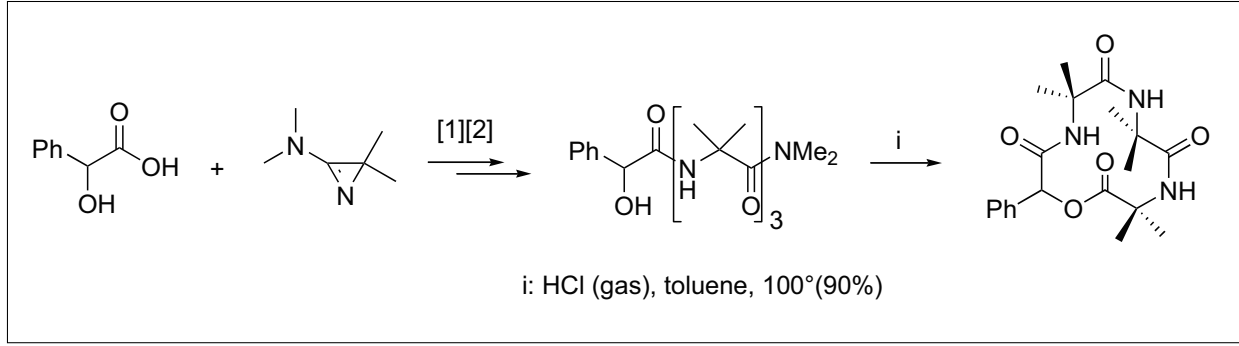

Fig. 1. Synthesis of cyclic depsipeptides by direct terminal amide cleavage via oxazolones 


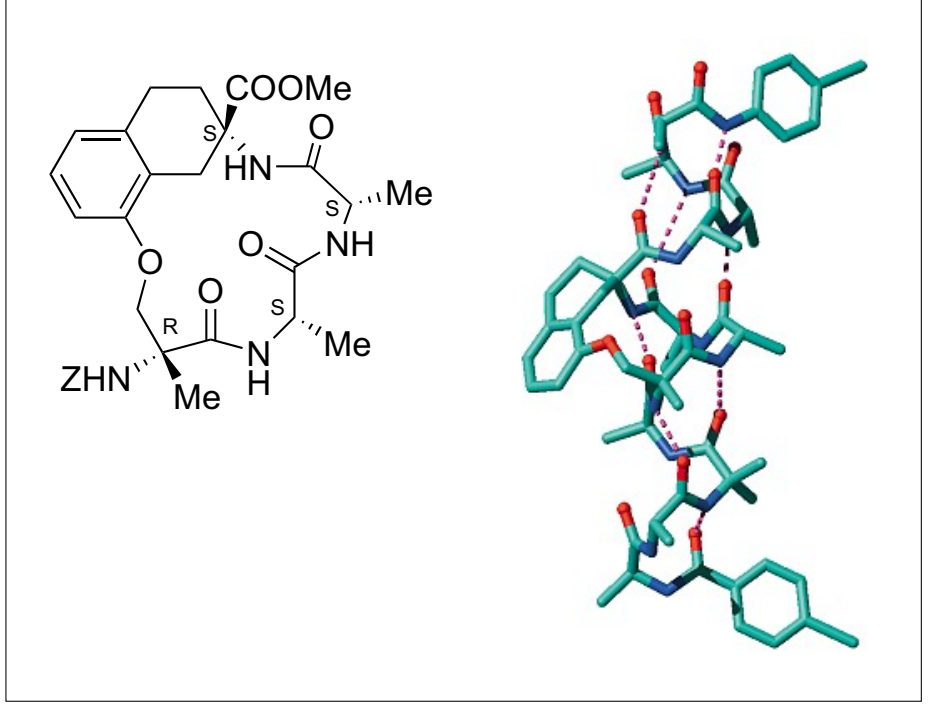

Fig. 2. Position-independent helix template ${ }^{[3]}$

rich. He was succeeded at Roche by Prof. Dr. Klaus Müller who initiated in 1989 a visionary project to develop small peptide mimetics derived from bioactive regions of pharmaceutically important proteins. Daniel had the chance to contribute to the creation of the group using his past experience from his PhD. thesis. Michael Altorfer joined this group as a $\mathrm{PhD}$ student working on position-independent peptide $\alpha$-helix mimetics of proteins ${ }^{[3]}$ (Fig. 2) under the guidance of Profs H.-J. Hansen, K. Müller and Daniel Obrecht.

In 1994 a paradigm shift occurred in the drug discovery process and the pharmaceutical industry discovered combinatorial chemistry. In this context the group started to explore concepts of synthesizing combinatorial libraries and to use parallel synthesis for lead optimization. During this period Daniel kept close contact to Profs. H.-J. Hansen and H. Heimgartner who also served as chemistry consultants for Roche. Furthermore, since 1995 Daniel had been given the opportunity to teach several courses and lectures on combinatorial chemistry, peptide mimetics and medicinal chemistry at the OCI.

\section{6-Present Day}

Jean-Pierre Obrecht's idea to start-up a company had been around for quite some time, however, discussions between JeanPierre and Daniel in that respect intensified during the course of 1996 (Jean-Pierre: "we need the right business idea and timing"). Jean-Pierre had undertaken his $\mathrm{PhD}$ in chemistry at the ETH in Prof. Dr. D. Arigoni's group and later worked as a postdoc in Prof. Dr. A. Vasella's group at the University of Zurich, and thus had his own link to the OCI. His work led to a new versatile asymmetric synthesis of $\alpha$-amino-phosphonic acids. ${ }^{[4]}$ After a career as research chemist at Maag in the agrochemical field he moved to Roche in Basel. In his last position he was responsible for the world-wide logistics of Roche's pharmaceutical active substances. Parallel to his job at Roche he made an MBA at the HSG in St. Gallen and gained a lot of management experience.

As of 1995 on it became increasingly clear that pharmaceutical companies were intensifying outsourcing of some of the early drug discovery activities to third parties. Offering general and focused libraries to the pharmaceutical industry seemed a good business idea: Polyphor Ltd was founded by Jean-Pierre and Daniel Obrecht in November 1996, strongly encouraged also by Prof. Dr. Jack Baldwin, FRS. Sir Jack Baldwin continues to be a Board Member of Polyphor. In parallel Prof. Dr. H.-J. Hansen as director of the OCI was able to convince his colleagues to offer some laboratory space and the excellent infrastructure of the institute to Polyphor for the start-up phase. Hence, Polyphor started its operations in February 1997 in Lab 32-F-44 with, initially, two additional co-workers. In the first phase the company synthesized focused libraries for Givaudan, Roche, Synthélabo (now Sanofi-Aventis), Wella and others. ${ }^{[5]}$ The company grew to 13 people and additional laboratory space on the $\mathrm{E}$ level could be rented temporarily. By end of 1999 Polyphor found a new home base at the Innovationszentrum in Allschwil and started operations with the turn of the new century. Meanwhile Daniel and Jean-Pierre Obrecht were able to convince Michael Altorfer, who after his $\mathrm{PhD}$ in chemistry started a successful career in investment banking at UBS, to join Polyphor's management team.

In parallel, other options of collaboration between the OCI and Polyphor were analyzed. It was more than a fortunate coincidence that Polyphor's laboratory was located on the same floor at the OCI as Prof. Dr. J. A. Robinson's group. After intense discussions it was agreed to jointly develop the Protein Epitope Mimetic (PEM) Technology.[6] PEM Technology targets large surface protein-protein interactions (PPIs) of therapeutic interest. PEM molecules are template-fixed cyclopeptide-like molecules which can mimic the $\beta$-hairpin and $\alpha$-helical secondary motifs of proteins often involved in PPIs (Fig. 3).

It was hoped that PEM Technology could ultimately provide a new class of drugs targeting difficult targets involving PPIs. Initial funding was obtained from the 'Kommission für Technik und Innovation' (KTI) and the project was started in 1999/2000. Promising first results were

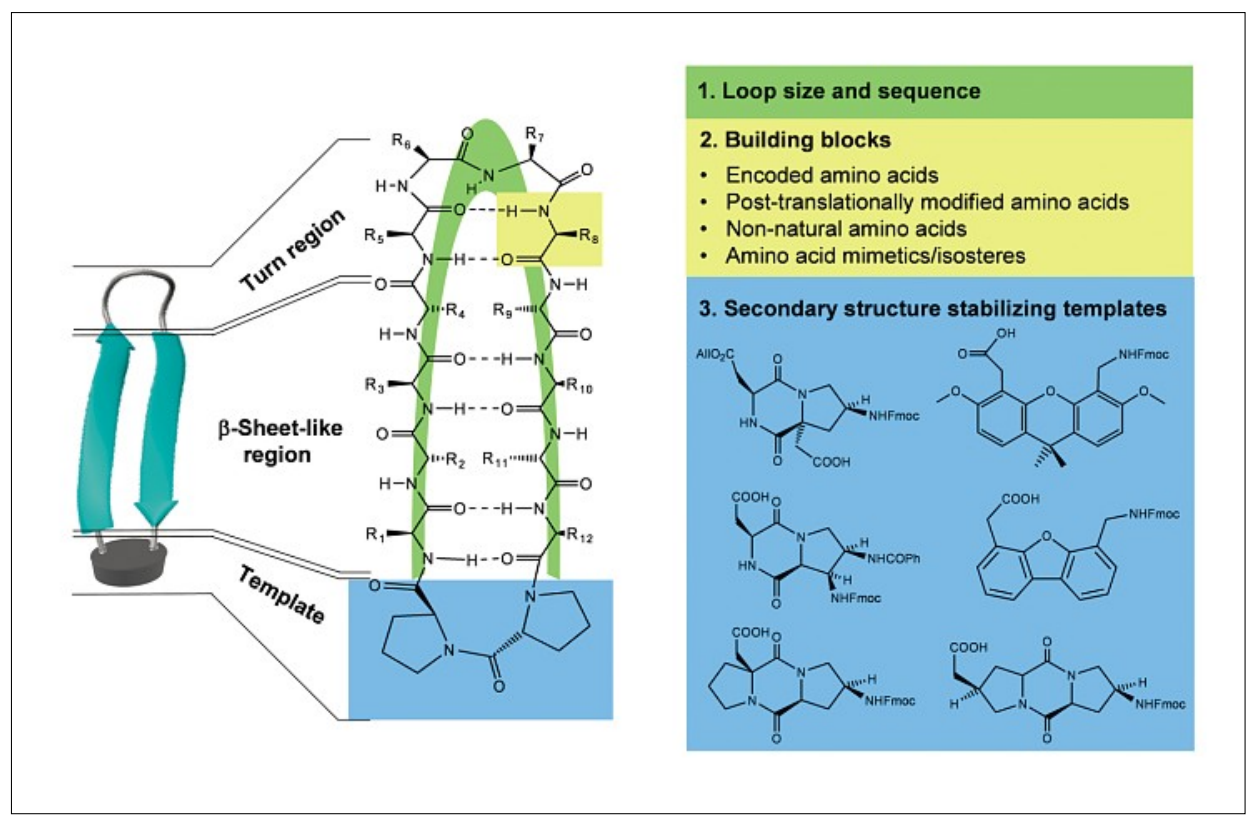

Fig. 3. PEM Technology: building blocks that can be varied 


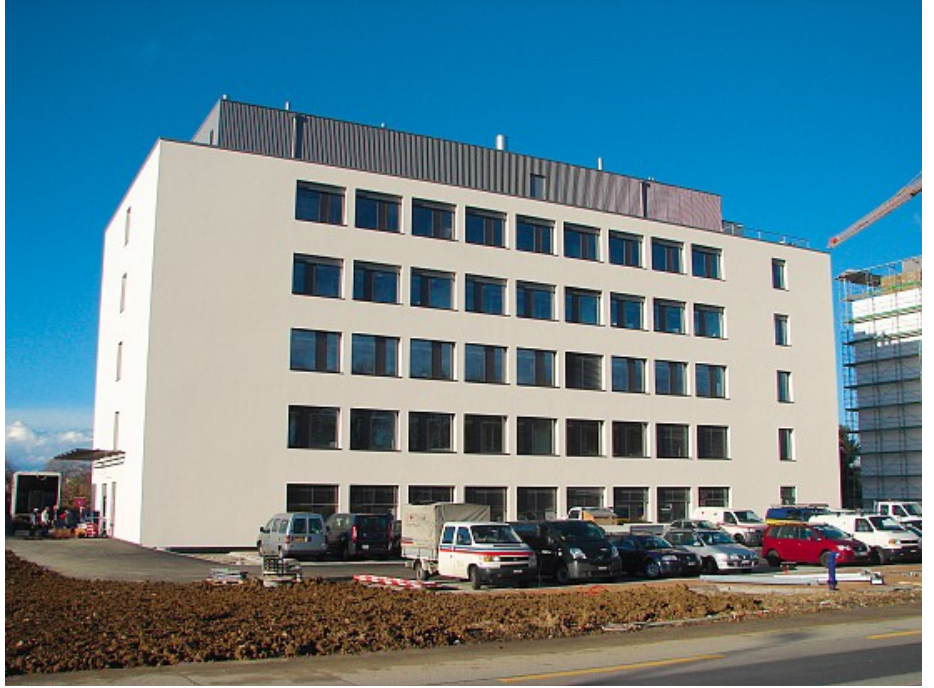

Fig. 4. New Polyphor site in Allschwil

generated which enabled Polyphor to convince private and corporate investors to invest into this new promising technology. As of 2001 up to 20 scientists from Prof. John Robinson's group and Polyphor worked on the further development of PEM Technology. Subsequently, two business units were created: the small molecule business unit (SMBU) in Allschwil and the Protein Epitope Mimetics business unit (PEMBU) at the University of Zurich. At the beginning of 2005 the PEMBU moved to the Rosental site in Basel. In 2007, a second KTI project between the University group and Polyphor has been approved and started in September, thus further strengthening the excellent collaboration. The intense collaboration efforts culminated in 2007 in a first successful approval of a PEM molecule for phase I clinical trials. POL6326 is a highly potent CXCR4 antagonist with potential therapeutic use in hematopoetic stem cell transplant, cancer, inflammation and other indications. ${ }^{[7]}$ The joint effort between the University group and Polyphor has generat- ed several additional interesting hit and lead compounds for other indications. In 2008 Polyphor will relocate its now more than 80 employees to a new research building in Allschwil (Fig. 4), thus uniting SMBU and PEMBU under one roof.

\section{Concluding Remarks}

The University of Zurich has played a key role in our scientific and professional lives. First, as Alma Mater, where Daniel Obrecht and Michael Altorfer received an excellent education and training as chemists; later by serving as incubator during the start-up phase for the company Polyphor. In addition, the OCI played a critical role in supporting the collaboration between Prof. John Robinson and Polyphor to develop PEM Technology. Hence, the University's vision to promote interactions between top basic science and pharmaceutical industry experience, substantially contributed to the development of PEM Technology and ulti- mately to a new class of drug candidates to treat serious medical needs such as cancer, inflammation and nosocomial blood stream and lung infections.

We would like to congratulate the University of Zurich for 175 years of chemistry and wish the OCI the best possible future. We would like to thank Profs. H.-J. Hansen, H. Heimgartner, M. Hesse, J. A. Robinson, and J. Siegel for their ongoing support. In addition we would like to thank Profs. Sir Jack Baldwin (Oxford), A. Vasella (ETH) and Dr. G. Haas (former head R\&D Ciba) for continuous advice and support.

Received: January 22, 2008

[1] D. Obrecht, '3-Amino-2H-azirine als Aminosäure-Aequivalente in der organischen Synthese', Inaugural Dissertation, University of Zurich, 1983.

[2] D. Obrecht, H. Heimgartner, Tetrahedron Lett. 1983, 24, 1921; D. Obrecht, H. Heimgartner, Helv. Chim. Acta 1984, 67, 526.

[3] M. Altorfer, 'Templates for the positionindependent nucleation of $\alpha$-helices in peptides', Inaugural Dissertation, University of Zurich, 1996.

[4] R. Huber, A. Knierzinger, J.-P. Obrecht, A. Vasella, Helv. Chim. Acta 1985, 68, 1730.

[5] P. Ermert, D. Obrecht, J.-P. Obrecht, K. Sekanina, Chimia 2000, 54, 198; M. Altorfer, P. Ermert, J. Fässler, S. Farooq, E. Hillesheim, A. Jeanguenat, K. Klumpp, P. Maienfisch, J. A. Martin, J. H. Merrett, K. E. B. Parkes, J.-P. Obrecht, T. Pitterna, D. Obrecht, Chimia 2003, 57, 262.

[6] L. Jiang, K. Moehle, B. Dhanapal, D. Obrecht, J. A. Robinson, Helv. Chim. Acta 2000, 83, 3097.

[7] S. J. DeMarco, H. Henze, A. Lederer, K. Moehle, R. Mukherjee, B. Romagnoli, J. A. Robinson, F. Brianza, F. O. Gombert, S. Lociuro, C. Ludin, J.-W. Vrijbloed, J. Zumbrunn, J.-P. Obrecht, D. Obrecht, V. Brondani, F. Hamy, T. Klimkait, Bioorg. Med. Chem. 2006, 14, 8396. 